\title{
INTEGRASI KAWASAN INDUSTRI MILLENNIUM KECAMATAN TIGARAKSA KABUPATEN TANGERANG DENGAN WILAYAH SEKITAR MENUJU KOTA INDUSTRI
}

\author{
Kokoh Widyastoro ${ }^{1}$, Paramita Rahayu ${ }^{1}$, Erma Fitria Rini ${ }^{1}$ \\ 1 Program Studi Perencanaan Wilayah dan Kota, Fakultas Teknik, Universitas Sebelas Maret
}

\begin{abstract}
Abstrak
Pemerintah Kabupaten Tangerang berencana mengembangkan kota industri di Kabupaten Tangerang. Kota industri merupakan sebuah kota yang terintegrasi yang menggabungkan kawasan industri, kawasan hunian, dan kawasan komersial dengan konsentrasi kegiatan penduduk yang tinggi. Pengembangan kota industri terdapat beberapa elemen yang perlu diintegrasikan diantaranya yaitu pemisahan guna lahan industri, konektivitas antar guna lahan, aksesibilitas, infrastruktur dan permukiman di sekitarnya. Kawasan Industri Millennium merupakan kawasan industri terbesar di Kabupaten Tangerang yang berkembang di pusat pemerintahan Kabupaten Tangerang. Tujuan dari penelitian ini adalah untuk mengetahui sejauh mana integrasi Kawasan Industri Millennium dengan wilayah di sekitarnya dalam menuju kota industri. Penelitian ini menggunakan metode kuantitatif dengan menggunakan analisis deskriptif dengan Skala Guttman. Analisis dilakukan pada masing-masing sub variabel yang didukung dengan analisis space syntax, SIG dan analisis VCR untuk mengkonfirmasi nilai pada Skala Guttman. Hasil analisis menunjukan Kawasan Industri Millennium telah terintegrasi dalam hal rencana pemisahan guna lahan, aksesibilitas, ketersediaan RTH publik, dan kelengkapan infrastruktur industri. Sementara itu pada elemen ketersediaan zona pemisah industri, konektivitas dan lokasi permukiman masih belum terintegrasi. Berdasarkan teori, isu dan hasil analisis maka diperoleh integrasi Kawasan Industri Millennium dengan wilayah sekitarnya telah memenuhi $50 \%$ dari syarat-syarat menuju kota industri terintegrasi.
\end{abstract}

Kata kunci: infrastruktur industri; integrasi; kawasan industri; kota industri; ruang terbuka hijau publik

\begin{abstract}
The Tangerang Regency has been planning to develop an industrial city in their administrative region. An industrial city is an integrated city that combines industrial estates, residential areas, and commercial areas with a high concentration of population and activities. The development of industrial city has several elements that need to be integrated including the separation of industrial land use, land-use connectivity, accessibility, infrastructure and settlements in the surrounding industrial estate. The case study is Millennium industrial estate, the largest industrial estate developing in the central area of Tangerang Regency. The purpose of this study is to understand to what extent the Millennium industrial Estate is integrated with surrounding areas towards fulfilling the concept of industrial city. This research uses quantitative methods, specifically the the Guttman Scale. The integration analysis is performed on each sub-variable supported by using space syntax, GIS and VCR analysis to confirm the value of the Guttman Scale. The results of the analysis showed that the Millennium industrial estate has been integrated in terms of land use planning, accessibility, availability of public green space, and industrial infrastructures. While the other elements which are availability of industrial separation zones, connectivity and location of settlements are still not integrated yet. Based on the theory, issues and analysis, the results show that the integration of the Millennium industrial Estate with the surrounding areas has fulfilled $50 \%$ of the requirements to develop an integrated industrial city.
\end{abstract}

Keywords: industrial city; industrial estate; industrial infrastructure; integration; public green space

\section{PENDAHULUAN}

Sektor industri merupakan sektor potensial yang memiliki peranan penting dalam pembangunan ekonomi suatu negara. Menurut UU No 3 Tahun 2014 tentang Perindustrian, industri adalah kegiatan ekonomi yang mengolah bahan baku dan/atau memanfaatkan sumber daya sehingga menghasilkan barang yang mempunyai nilai tambah. Kawasan industri adalah suatu daerah yang didominasi oleh kegiatan industri yang mempunyai fasilitas kombinasi terdiri dari peralatan-peralatan pabrik (industrial plants), sarana penelitian dan laboratorium untuk pengembangan, bangunan perkantoran, bank, serta fasilitas sosial dan fasilitas umum (Dirdjojuwono, 2004). Perkembangan industrialisasi yang 
pesat selain memberikan dampak pada peningkatan ekonomi, industrialisasi juga memberikan multiplier effect di bidang sosial dan ekologi seperti perubahan struktur sosial masyarakat dan pencemaran lingkungan (Abdullah, 2010). Untuk mengoptimalkan potensi dan mengurangi resiko dari perkembangan sektor industri maka diperlukan perencanaan kota atau wilayah agar industri dan kegiatan lain di sekitarnya seperti permukiman, perdagangan dan sebagainya dapat bersinergis yaitu kota industri. Kota industri merupakan sebuah kota yang terintegrasi yang menggabungkan kawasan industri, kawasan hunian, dan kawasan komersial dengan konsentrasi kegiatan penduduk yang tinggi (Nurmayanti, 2017).

Kabupaten Tangerang merupakan daerah hinterland Kota Tangerang yang juga berfungsi sebagai penyangga Ibukota DKI Jakarta di bidang industri dan manufaktur. Perkembangan industri di Kabupaten Tangerang telah berkembang sangat pesat, sektor industri dan manufaktur juga telah menyumbang 53,08\% Pendapatan Domestik Regional Bruto Kabupaten Tangerang. Melihat potensi dan kondisi sektor industri Pemerintah Kabupaten Tangerang, Ahmed Zaki Iskandar berencana untuk mengembangkan kota industri di Kabupaten Tangerang. Sebagaimana yang dinyatakan dalam kebijakan RTRW Kabupaten Tangerang yang bertujuan untuk mewujudkan kabupaten sebagai pusat kegiatan pusat kegiatan industri, permukiman, dan pengembangan kawasan perkotaan baru Pantura yang berwawasan lingkungan dan berdaya saing menuju masyarakat madani didukung oleh pertanian yang berkelanjutan melalui pengembangan pusat-pusat pertumbuhan, konsep kota industri ini masih sejalan dengan tujuan dari RTRW Kabupaten Tangerang.

Berdasarkan Rencana RTRW Kabupaten Tangerang pengembangan kawasan peruntukan industri besar dikembangkan seluas $8.407 \mathrm{Ha}$ di enam kecamatan dan salah satunya adalah Kecamatan Tigaraksa. Kawasan Industri Millennium merupakan kawasan industri terbesar di Kabupaten Tangerang yang berada di perbatasan antara Kecamatan Cikupa dan Kecamatan Tigaraksa dengan luas lahan sebesar $1.800 \mathrm{Ha}$. Kawasan ini mengusung konsep "Green Industry" dan memperhatikan estetika serta kelestarian dari lingkungan sekitar. Kawasan Industri Millennium juga menjadi prioritas dalam pengembangan kawasan industri (Fachira, 2017). Pengembangan kota industri di Kabupaten Tangerang perlu mengintegrasikan kawasan industri dengan wilayah sekitarnya. Pengertian integrasi sendiri menurut Widjaja (1986) adalah keserasian dari beberapa komponen yang terdapat dalam suatu sistem, namun merupakan komponen yang berbeda serta tidak merugikan masing masing satuan. Maka dalam konteks kota industri, sebuah kota industri merupakan gabungan gabungan dari kawasan industri, hunian dan komersil serta guna lahan lain yang terpadu dan memiliki keterkaitan dan konektivitas antara satu dengan yang lain dan memberikan efek saling menguntungkan. Dalam menuju kota industri perlu mengintegrasikan antara kawasan industri dan kawasan disekitarnya, oleh karena itu, penelitian ini ingin mengetahui sejauh mana integrasi Kawasan Industri Millennium dan wilayah sekitarnya dalam menuju kota industri.

\section{KAJIAN PUSTAKA}

Penelitian ini merupakan penelitian kuantitatif yang menggunakan teori-teori terkait sebagai landasan dalam melakukan penelitian. Kajian teori yang digunakan dalam menentukan variabel penelitian dan indikator dijabarkan sebagai berikut.

\subsection{KOTA INDUSTRI}

Kota industri (industrial city) adalah sebuah wilayah perkotaan dimana kegiatan pengolahan atau manufaktur mendominasi perekonomian lokal yang akan berdampak pada lingkungan dan hubungan sosial masyarakatnya (Harris, 2009). Konsep kota industri pertama kali diperkenalkan oleh Tony Garnier (1917) dengan nama Cite Indutrielle' beliau menetapkan (1) pemisahan penggunaan lahan berdasarkan fungsinya. Zona tersebut yaitu kawasan hunian, industri, ruang publik dan pertanian. (2) Masing masing kawasan dihubungkan dengan jaringan dan pola sirkulasi baik dengan kendaraan maupun jalur pedestrian. (3) Zona hunian ditempatkan pada lokasi yang ideal dan tidak terkena polusi dari kegiatan industri dan nyaman. (4) Zona industri berada pada lokasi yang aksesibel baik untuk memperoleh sumber daya ataupun transportasi (Wiebenson, 1960).

Robert Phelps (1995) membuat konsep pengembangan Modern Industrial City di Torrance, California dan Raymond \& Neil (1972) yang juga mengilustrasikan pengembangan kota industri di US Steel, US. Kedua ahli tersebut membuat karakteristik kota industri dalam perencanaan menggunakan (1) pemisahan penggunaan lahan berdasarkan fungsinya yang mana kawasan hunian, bisnis dan industri dipisahkan oleh tembok yang disebut border avenue dimana (2) masing masing distrik dihubungkan oleh jaringan jalan dan sarana transportasi. (3) Selain itu kawasan industri ditempatkan pada 
lokasi yang aksesibel dan dapat dijangkau melalui jalan permukaan maupun rel kereta api. Robert Phelps melengkapi konsep tersebut dengan menambah (4) jalur sirkulasi untuk bahan bahan produksi industri dibedakan dengan jalur komersial untuk mempermudah akses distribusi industri dan tidak mengganggu sirkulasi perdagangan dan jasa yang lain. (5) Kemudian di Kota Torrance terdapat taman kota yang dijadikan sebagai pusat bagi masyarakat untuk berkumpul dan bersosialisasi. Pihak manajemen kawasan industri menyediakan rumah bagi masyarakat yang bekerja di kawasan industri Torrance dengan manajemen yang diatur oleh pihak industri. (6) Lokasi permukiman juga dibuat dibuat tidak searah dengan arah angin dan industri agar polusi asap industri tidak mencapai pada zona permukiman.

Pengembangan kota industri modern pada kawasan Neyveli di India yang dillustrasikan Prabhakar (2015). Transportasi di dalam kota terlayani dengan pelayanan bis, terhubung dengan dua jalan raya yang mengelilingi kawasan Neyveli, dan terhubung dengan jaringan rel kereta api. Kota Neyvely juga terfasilitasi oleh jaringan listrik, air, kesehatan, sanitasi, dan taman. Prabhakar (2015) juga menggambarkan kota industri di Jhamsedpur, India. Jhamsedpur merupakan kota pertama di India yang dikembangkan sebagai kota industri. Dari segi transportasi, kota ini memiliki konektivitas yang baik oleh rel kereta api dan jaringan jalan dan terlayani bandara kecil untuk melayani mobilitas kota. Kota Jhamsedpur terlayani Jubilee Park yang merupakan pemberian dari perusahaan industri Tata Steel untuk melayani masyarakat pada kota tersebut.

Dari pernyataan para ahli seperti pada paragraf di atas maka dapat diketahui bahwa karakteristik kota industri antara lain (1) pemisahan penggunaan lahan, (2) konektivitas antar guna lahan, (3) aksesibilitas, (4) terfasilitasi infrastruktur, (5) ketersediaan ruang terbuka publik, (6) ketersediaan jalur distribusi industri, dan (7) lokasi permukiman yang tidak terkena polusi industri. Variabel ini akan digunakan dalam penelitian ini, kemudian tiap-tiap variabel akan dijelaskan dalam sub bab selanjutnya.

\subsection{PEMISAHAN PENGGUNAAN LAHAN}

Soil Conservation Society of America (1982) dalam Sitorus (2016) menyatakan perencananaan penggunaan lahan merupakan proses inventarisasi dan penilaian keadaan, potensi dan pembatas-pembatas dari suatu daerah tertentu dan sumber dayanya yang berinteraksi dengan orang yang menaruh perhatian terhadap daerah tersebut dalam menentukan kebutuhan-kebutuhan mereka, keinginan dan aspirasinya untuk masa mendatang. Perencanaan penggunaan lahan diatur dalam rencana pola ruang, dimana rencana pola ruang berfungsi sebagai pengatur keseimbangan dan keserasian peruntukan ruang (PermenPu No 16 Tahun 2009).

Membangun suatu kawasan sama halnya membangun suatu kota, hanya saja lebih spesifik jenis kegiatannya. Oleh karena itu dalam mengembangkan kawasan industri perlu disediakan kawasan permukiman dan kawasan komersial (Dirdjojuwono, 2004). Pengembangan zona komersial di sekitar kawasan industri cenderung dikembangkan di sepanjang koridor jalan utama dan zona industri berada pada 60 meter dari jalan utama. Keadaan ini adalah untuk menjadikan zona komersial sebagai zona penyangga antara industri dan permukiman (Dirdjojuwono, 2004). Pemisahan antara industri dengan wilayah sekitarnya juga dapat dilakukan dengan menempatkan zona taman, pertanian ataupun fungsi hijau lain sebagai zona transisi antara industri dan kawasan permukiman, sebagaimana konsep Ebenezer Howard dalam bukunya Garden City Of Tomorrow (Catanese dan Snyder, 1988).

\subsection{KONEKTIVITAS DAN AKSESIBILITAS}

Pengembangan kota industri transportasi menjadi sebuah kunci untuk memperoleh bahan baku dan mendistribusikan hasil produksi industri (Catanese dan Snyder, 1988). Konektivitas antar ruang dapat diukur melalui analisis space syntax. Analisis space syntax mempergunakan dimensi yang diukur dengan menggunakan konsep jarak topologi yang disebut kedalaman (depth) (Siregar, 2014). Kedalaman (depth) diukur dalam langkah (step) yang disebut jarak topologis atau topological distance (Hillier et al, 1987 dalam Siregar, 2014). One step depth berarti jarak antara dua buah ruang yang terhubung secara langsung (lihat Gambar 1). Konsep depth merupakan dimensi yang dipergunakan untuk tahap selanjutnya dalam analisis space syntax yaitu connectivity dan integrity. Connectivity adalah dimensi yang mengukur properti lokal dengan cara menghitung jumlah ruang yang secara langsung terhubung dengan masing-masing ruang lainnya dalam suatu konfigurasi ruang (Hillier et al, 1993 dan Hillier et al, 1987). Integrasi adalah dimensi selanjutnya setelah connectivity, yang dalam perhitungan nilainya juga melibatkan ruang-ruang yang tidak terkoneksi secara langsung (Siregar, 2014). 


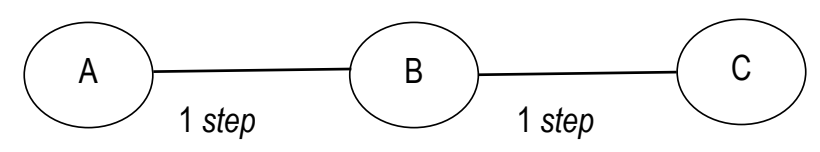

Sumber: Siregar, 2014

Gambar 1. Konsep Step Depth Space Syntax

Aksesibilitas merupakan faktor yang menjadi daya tarik dalam pengembangan kawasan industri (Sukandar, 2015). Leksono et al dalam Audistiana (2017) menjelaskan pengertian aksesibilitas yaitu tingkat mudah atau sulitnya suatu lokasi dicapai melalui transportasi. Menurut Tarigan (2005) tingkat aksesibilitas dipengaruhi oleh jarak, kondisi prasarana hubungan, ketersediaan sarana penghubung termasuk frekuensinya dan tingkat keamanan serta kenyamanan. Aksesibilitas jaringan jalan sangat dipengaruhi oleh tingkat pelayanan jalan. Tingkat pelayanan jalan merupakan ukuran yang digunakan untuk mengetahui kualitas ruas jalan tertentu dalam melayani arus lalu lintas yang melewatinya (Sukandar, 2015). Tingkat pelayanan jalan dapat dihitung dengan menggunakan Manual Kapasitas Jalan Indonesia (MKJI, 1997) dengan rumus sebagai berikut:

$$
V C R=\frac{V}{C}
$$

Keterangan: $\quad$ VCR $=$ Volume Capacity Ratio (nilai tingkat pelayanan)

$\mathrm{V} \quad=$ Volume lalu lintas (smp/jam)

C = Kapasitas Ruas Jalan (smp/jam)

Menurut Permenperin No 35 Tahun 2010 tentang Pedoman Teknis Kawasan Industri, untuk pengembangan kawasan industri harus terlayani oleh jalan arteri primer, suatu kawasan dinilai sesuai untuk kegiatan industri jika berada pada radius $5 \mathrm{~km}$ dari jalan arteri primer (Destralita, 2015). Hal ini supaya distribusi baik untuk bahan baku atau pemasaranan menggunakan kendaraan truk container dan perlunya akses utama ke pelabuhan/bandara. Dari pernyataan tersebut maka dapat diketahui bahwa jalur distribusi untuk suatu kawasan industri adalah jalan arteri primer.

\subsection{INFRASTRUKTUR}

Kegiatan industri merupakan salah satu aktivitas ekonomi yang juga sangat memerlukan infrastruktur, kawasan industri tidak akan mampu berkembang tanpa infrastruktur (Arsyad, 2005 dalam Sutanta, 2010). Berdasarkan Peraturan Menteri Perindustrian No 35 Tahun 2010, perusahaan kawasan industri harus mengusahakan penyediaan prasarana dan sarana, sekurang-kurangnya antara lain jaringan jalan dalam kawasan industri sesuai ketentuan yang berlaku, saluran drainase, instalasi penyediaan air bersih, IPAL, instalasi penyediaan dan jaringan distribusi tenaga listrik, instalasi penyediaan dan jaringan distribusi/pipa gas, jaringan telekomunikasi, penerangan jalan, unit perkantoran kawasan industri, unit pemadam kebakaran dan fasilitas umum (masjid, gereja, pertokoan, dll).

\subsection{RUANG TERBUKA HIJAU}

Keberadaan RTH secara umum bertujuan untuk menjaga kelestarian, keserasian dan keseimbangan ekosistem yang terdiri dari unsur-unsur lingkungan, sosial dan budaya (Saraswati, 2008). Departemen Pekerjaan Umum (2006) dalam Saraswati (2008) menjelaskan bahwa RTH yang berkatan dengan suatu kawasan industri dapat menjaga keseimbangan ekosistem dan dapat berfungsi sebagai penahan dan penyaring partikel padat dari udara serta mengurangi tekanan yang diakibatkan pencemaran lingkungan. Penyediaan ruang terbuka bergantung kepada luas lahan dan jumlah penduduk yang dilayani. Berdasarkan SNI 03-1733-2004 Tentang Tata Cara Perencanaan Lingkungan syarat dan kriteria penyediaan ruang terbuka publik adalah sebagaimana pada Tabel 1. 
Tabel 1. Kriteria Sarana Terbuka Perkotaan

\begin{tabular}{cccccc}
\hline No & \multicolumn{1}{c}{ Jenis Sarana } & $\begin{array}{c}\text { Jumlah } \\
\text { penduduk }\end{array}$ & $\begin{array}{c}\text { Luas lahan } \\
\text { minimal }\end{array}$ & $\begin{array}{c}\text { Standard } \\
\left(\mathrm{m}^{2} / \text { jiwa }\right)\end{array}$ & $\begin{array}{c}\text { Radius } \\
\text { pelayanan }\end{array}$ \\
\hline 1 & Taman/ tempat main & 250 & 250 & 1 & 100 \\
2 & $\begin{array}{l}\text { Taman/ tempat main } \\
3\end{array}$ & 2.500 & 1.250 & 0,5 & 1.000 \\
& $\begin{array}{l}\text { Taman dan lapangan } \\
\text { olahraga }\end{array}$ & 30.000 & 9.000 & 0,3 & \\
4 & $\begin{array}{l}\text { Taman dan lapangan } \\
\text { olahraga }\end{array}$ & 120.000 & 24.000 & 0,2 & \\
5 & Jalur hijau & $15 \mathrm{~m}$ & & \\
6 & $\begin{array}{l}\text { Kuburan / } \\
\text { pemakaman umum }\end{array}$ & 120.000 & & & \\
\hline
\end{tabular}

Sumber : SNI 03-1733-2004

\section{METODE PENELITIAN}

Pendekatan yang digunakan dalam penelitian integrasi Kawasan Industri Millennium dengan wilayah sekitarnya adalah pendekatan deduktif dengan jenis penelitian yang bersifat kuantitatif. Metode pengumpulan data dilakukan dengan survei untuk mengumpulkan data primer dan data sekunder. Survei untuk data primer dilakukan melalui observasi pada Kawasan Industri Millennium dan wilayah sekitarnya. Hal ini dilakukan untuk mencari data terkait sebaran dan kondisi sarana dan prasarana, serta kondisi lalu lintas pada kawasan penelitian. Survei untuk data sekunder dilakukan melalui studi dokumen atau literatur maupun informasi data terkait dari dinas maupun masyarakat setempat. Teknik sampling yang digunakan dalam penelitian ini adalah random sampling dengan populasi jumlah KK pada kawasan penelitian dengan asumsi 1 KK beranggotakan 5 orang (SNI 03-1733-2004). Diperoleh sampel sejumlah $100 \mathrm{KK}$ yang didistribusikan ke dalam sub wilayah penelitian berdasarkan luas wilayah permukiman pada masingmasing sub wilayah, lebih jelasnya dapat dilihat pada Gambar 2. Untuk variabel dan indikator pada penelitian ini dapat dilihat pada Tabel 2.

Tabel 2. Indikator Parameter Variabel

\begin{tabular}{|c|c|c|c|}
\hline Variabel & Sub Variabel & Indikator & Kriteria \\
\hline $\begin{array}{l}\text { Pemisahan } \\
\text { Penggunaan } \\
\text { Lahan }\end{array}$ & $\begin{array}{l}\text { Rencana pemisahan lahan } \\
\text { industri dan permukiman } \\
\text { Pemisahan guna lahan } \\
\text { industri dan permukiman } \\
\text { sekitar eksisting } \\
\end{array}$ & $\begin{array}{l}\text { Ketersediaan rencana pemisahan } \\
\text { industri dengan sekitarnya } \\
\text { Ketersediaan zona hijau sebagai } \\
\text { zona transisi antara industri } \\
\text { dengan guna lahan lain } \\
\end{array}$ & $\begin{array}{c}\text { Tersedianya rencana untuk pemisahan } \\
\text { lahan industri dengan sekitarnya } \\
\text { Tersedianya zona transisi berupa zona } \\
\text { hijau disekitar industri (Sumber: Lovejoy, } \\
\text { 1979) }\end{array}$ \\
\hline $\begin{array}{l}\text { Konektivitas } \\
\text { Antar Guna } \\
\text { Lahan }\end{array}$ & & Nilai integration space syntax & $\begin{array}{c}\text { Nilai integration sedang hingga tinggi } \\
\text { (Sumber: Analisis Space Syntax diambil } \\
\text { dari Siregar, 2014) }\end{array}$ \\
\hline Aksesibilitas & $\begin{array}{l}\text { Tingkat pelayanan jalan } \\
\text { Ketersediaan moda } \\
\text { transportasi angkutan umum } \\
\text { Ketersediaan jalur distribusi } \\
\quad \text { industri }\end{array}$ & $\begin{array}{c}\text { Kinerja jalan yang dilalui } \\
\text { kendaraan industri } \\
\text { Ketersediaan moda dan trayek } \\
\text { pelayanan angkutan umum } \\
\text { Jangkauan pelayanan jalan arteri } \\
\text { primer }\end{array}$ & $\begin{array}{c}\text { Tingkat pelayanan jalan kelas A sampai C } \\
\text { (Sumber: MKJI, 1997) } \\
\text { Tersedianya jalur trayek angkutan umum } \\
\text { (Sumber: Suchaini, 2013) } \\
\text { Kawasan industri berada pada radius } 5 \\
\text { km dari jalan arteri primer (Sumber: } \\
\text { Destralita, 2015) } \\
\end{array}$ \\
\hline Infrastruktur & $\begin{array}{c}\text { Kelengkapan infrastruktur } \\
\text { industri }\end{array}$ & $\begin{array}{l}\text { Ketersediaan sarana dan } \\
\text { prasarana kawasan industri }\end{array}$ & $\begin{array}{l}\text { Ketersediaan sarana dan prasarana } \\
\text { kawasan industri secara lengkap } \\
\text { (Sumber: Permenperin No } 35 \text { Tahun } \\
\text { 2010) }\end{array}$ \\
\hline $\begin{array}{l}\text { Ruang } \\
\text { Terbuka } \\
\text { Publik }\end{array}$ & $\begin{array}{c}\text { Ketersediaan ruang terbuka } \\
\text { publik } \\
\text { Keterjangkauan ruang terbuka } \\
\text { publik }\end{array}$ & $\begin{array}{l}\text { Ketersediaan ruang terbuka } \\
\text { publik } \\
\text { Keterjangkauan ruang terbuka } \\
\text { publik }\end{array}$ & $\begin{array}{l}\text { Luas RTH publik minimal berdasarkan } \\
\text { SNI 03-1733-2004 } \\
\text { Kawasan penelitian terjangkau RTH publik } \\
\text { dengan radius } 1.000 \mathrm{~m}\end{array}$ \\
\hline $\begin{array}{l}\text { Permukiman } \\
\text { Tidak } \\
\text { Terdampak }\end{array}$ & Jarak permukiman & $\begin{array}{l}\text { Jarak lokasi permukiman dengan } \\
\text { industri }\end{array}$ & $\begin{array}{c}\text { Permukiman berada diluar radius } 2 \mathrm{~km} \text { dari } \\
\text { kawasan industri (Sumber: Permenperin } \\
\text { No } 35 \text { Tahun } 2010 \text { ) }\end{array}$ \\
\hline
\end{tabular}




\begin{tabular}{cccc}
\hline Variabel & Sub Variabel & Indikator & Kriteria \\
\hline $\begin{array}{c}\text { Negatif dari } \\
\text { Industri }\end{array}$ & $\begin{array}{c}\text { Dampak kegiatan industri } \\
\text { terhadap permukiman }\end{array}$ & $\begin{array}{c}\text { Dampak dari kegiatan industri } \\
\text { berdasarkan persepsi masyarakat } \\
\text { sekitar }\end{array}$ & $\begin{array}{c}\text { Kawasan permukiman sekitar industri } \\
\text { tidak terkena dampak negatif dari industri }\end{array}$ \\
$\begin{array}{c}\text { Keterlibatan manajemen } \\
\text { permukiman oleh industri }\end{array}$ & $\begin{array}{c}\text { Ada atau tidak peran serta } \\
\text { industri dalam manajemen } \\
\text { permukiman sekitar }\end{array}$ & $\begin{array}{c}\text { Manajemen industri terlibat dalam } \\
\text { manajemen permukiman di sekitarnya } \\
\text { (Sumber: Phelps, 1995) }\end{array}$ \\
\hline
\end{tabular}

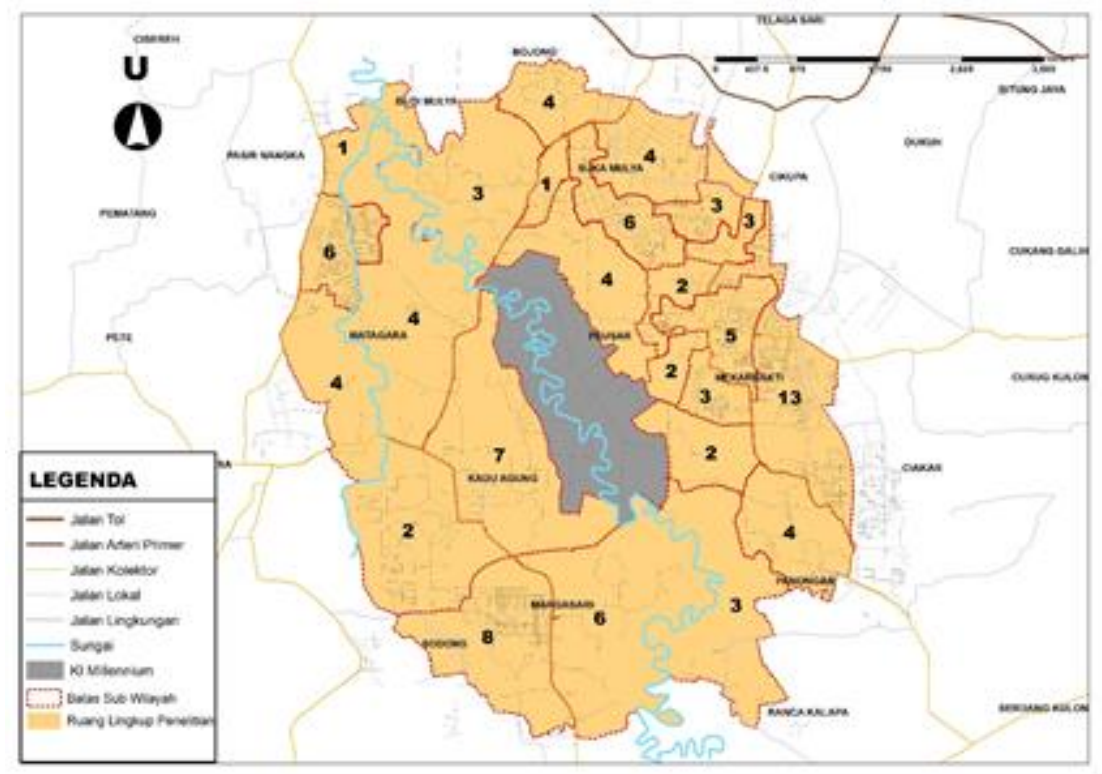

Gambar 2. Peta Pembagian Sub Wilayah dan Jumlah Sampel Tiap Sub Wilayah

Teknik analisis yang digunakan dalam penelitian ini adalah analisis deskriptif yang didukung melalui analisis SIG dan analisis space syntax. Analisis deskriptif dilakukan dengan Skala Guttman untuk memperoleh ketegasan dari hasil identifikasi dari masing-masing variabel.

\section{HASIL DAN PEMBAHASAN}

Berdasarkan hasil analisis, dalam hal ini akan dijabarkan mengenai pembahasan dari hasil analisis skoring tiap varibel. Berikut ini merupakan penjabaran dari hasil analisis:

\section{a. Pemisahan Penggunaan Lahan Industri dan Permukiman Sekitar}

Pemisahan penggunaan lahan dilihat dari ketersediaan rencana terkait zona pemisah antara industri dan wilayah sekitarnya dan ketersediaan zona hijau eksisting sebagai zona transisi. Kabupaten Tangerang telah memiliki aturan penyediaan zona hijau bagi industri sebagai zona transisi yaitu pada Perda Kabupaten Tangerang No 9 Tahun 2006 tentang rencana tapak yang menyatakan bahwa lahan efektif untuk kawasan industri diperbolehkan maksimal $60 \%$ dari total luas lahan dan $40 \%$ sisanya digunakan untuk fasilitas umum dan sarana prasarana. Dalam lahan efektif $60 \%$ di dalamnya pengembangan lahan terbangun untuk kegiatan industri hanya diperbolehkan $70 \%$ dan $30 \%$ nya diharuskan untuk pengembangan $\mathrm{RTH}$.

Selanjutnya dalam kondisi eksistingnya Kawasan Industri Millennium belum secara keseluruhan wilayah kawasan industri memiliki zona transisi berupa zona hijau sebagai pemisah antara industri dan permukiman sekitar. Masih adanya permukiman yang berbatasan langsung dengan industri dan hanya dibatasi oleh dinding beton sebagai pembatas wilayah dan bukan zona hijau. Untuk lebih detailnya dapat dilihat dalam Gambar 3. 


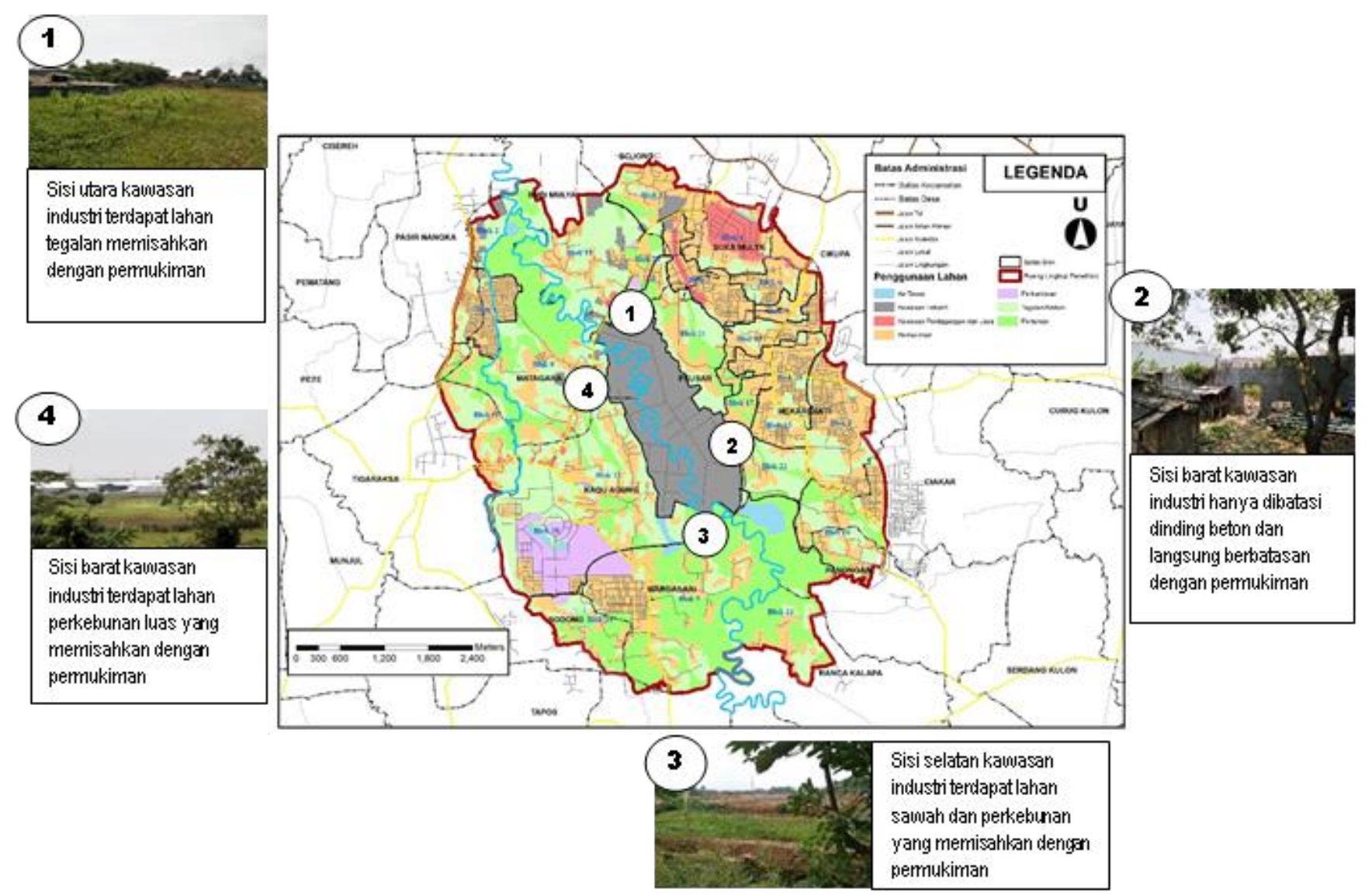

Gambar 3. Peta Ketersediaan Zona Transisi Kawasan Industri dengan Sekitarnya

\section{b. Konektivitas dan Aksesibilitas}

Kawasan penelitian yang didominasi kawasan permukiman telah terhubung jaringan jalan dengan penggunaan lahan lain baik industri, perkantoran maupun perdagangan dan jasa. Kondisi jaringan jalan pada kawasan industri Millenium dan wilayah sekitarnya memiliki kondisi yang baik perkerasan jalan di dalam Kawasan Industri Millennium yaitu aspal dengan lebar jalan $7 \mathrm{~m}$ di setiap lajur. Pada wilayah sekitarnya mayoritas menggunakan perkerasan aspal dan beton. Berdasarkan analisis space syntax, kawasan penelitian dibagi menjadi 3 kategori tingkatan integrasi. Berikut adalah klasifikasi nilai integration space syntax (lihat Tabel 3):

Tabel 3. Klasifikasi Nilai Integration Space Syntax

\begin{tabular}{cc}
\hline Nilai Integration & Klasifiikasi \\
\hline $0,262366-0,407$ & Integrasi Rendah \\
$0,40701-0,551835$ & Integrasi Sedang \\
$0,551836-0,696569$ & Integrasi Tinggi \\
\hline
\end{tabular}

Integrasi di dalam kawasan penelitian yang terdiri dari perumahan, perkantoran, perdagangan dan jasa, dan lahan non terbangun. Dari hasil analisis tersebut diketahui bahwa wilayah yang memiliki integrasi rendah yaitu wilayah Desa Ciakar, Margasari, Kaduagung dan Matagara, integrasi sedang yaitu sebagian wilayah Desa Kaduagung, Margasari, dan Mekarbakti. Selanjutnya wilayah dengan integrasi tinggi yaitu sebagian wilayah Desa Mekarbakti, Kaduagung, Budimulya, Bojong dan Matagara serta seluruh wilayah Desa Peusar, Sukamulya dan Cikupa. Wilayah yang memiliki tingkat integrasi tinggi merupakan yang paling mudah untuk dijangkau dari seluruh kawasan lainnya dalam lingkup wilayah penelitian yang berarti wilayah tersebut memiliki konektivitas yang baik dengan Kawasan Industri Millennium. Sebaliknya wilayah dengan nilai integrasi rendah wilayah tersebut cenderung terpisah secara konfigurasi ruang (kawasan penelitian) yang berarti untuk menuju ruang tersebut perlu melewati beberapa daerah agar dapat menuju wilayah tersebut. Maka dari hasil analisis ini terdapat wilayah dengan integrasi rendah sehingga masih belum memenuhi indikator kota industri. Untuk lebih jelasnya dapat dilihat pada Gambar 4. 


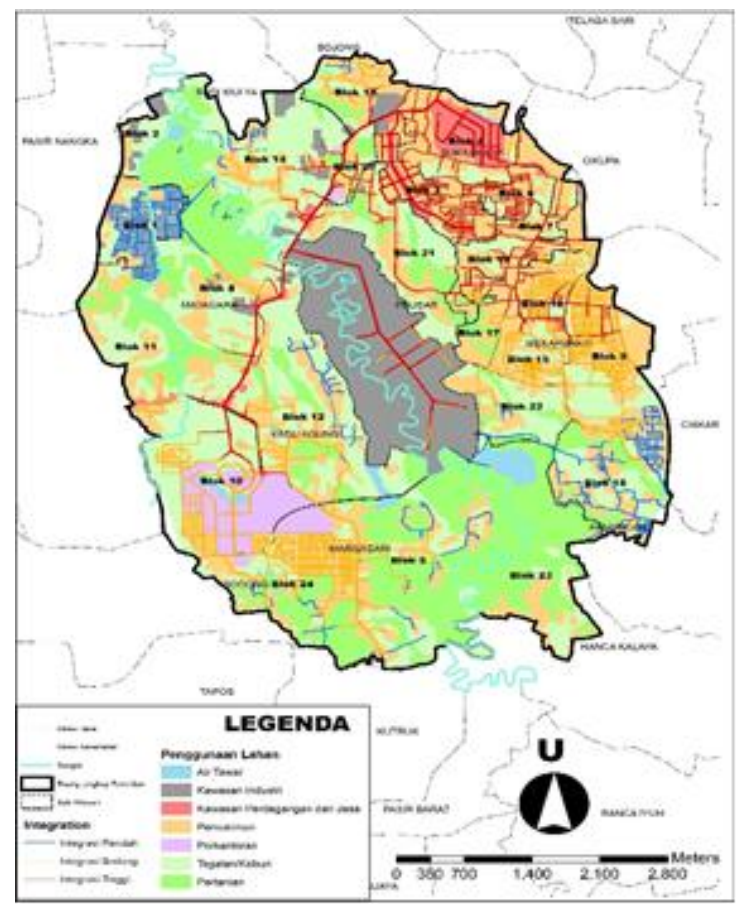

Gambar 4. Peta Hasil Analisis Integration Space Syntax

Salah satu faktor aksesibilitas suatu wilayah adalah kondisi lalu lintas, tingkat pelayanan jalan mampu memberikan gambar kondisi lalu lintas pada suatu kawasan. Berikut adalah hasil perhitungan kinerja jalan pada jalan-jalan yang dilalui oleh kendaraan industri yaitu Jl. Syekh Nawawi, Jl. Raya Tigaraksa, dan Jl. Kaduagung:

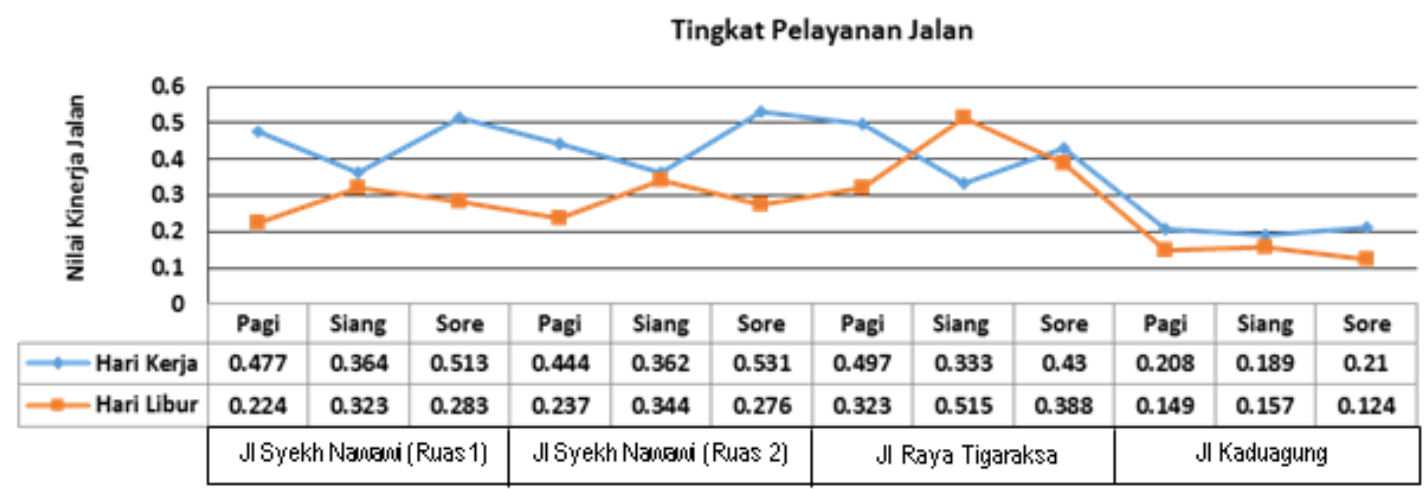

Gambar 5. Diagram Kinerja Jalan yang Dilalui Kendaraan Industri

Berdasarkan Gambar 5 diketahui bahwa kinerja jalan pada Jl. Syekh Nawawi, Jl. Raya Tigaraksa, dan Jl. Kaduagung masih dalam kondisi stabil, yang berarti jaringan jalan masih mampu menampung arus kendaraan baik dari industri maupun aktivitas lain tetap dan dalam pengembangan industri Millennium mempertimbangkan kondisi arus lalu lintas di sekitarnya agar lalu lintas tetap stabil. Analisis ini mengacu pada standar MKJI (1997) bahwa setiap derajat kejenuhan memiliki karakteristik lalu lintas yang berbeda. Pada kawasan penelitian derajat kejenuhan tertinggi yaitu tingkat pelayanan kelas $C(0.45-0,74)$ yang berarti kondisi arus lalu lintas masih cenderung stabil.

Faktor lain dari aksesibilitas yakni sarana transportasi. Dalam menganalisis ketersediaan sarana transportasi penulis melakukan observasi untuk mengetahui ketersediaan trayek angkutan umum yang melintasi kawasan penelitian. Kawasan sekitar industri Millennium telah terlayani 3 trayek angkutan umum yaitu A06, A09 dan E10. Untuk jalur trayek angkutan umum lebih jelas dapat dilihat pada Gambar 6. Analisis ini dilakukan berdasarkan Suchaini (2013) yang menyatakan moda transportasi (angkutan umum) merupakan elemen penting yang akan memfasilitasi tenaga kerja industri untuk menuju kawasan industri.

Kawasan industri memerlukan jalur khusus untuk mendistribusi barang hasil produksi dan disribusi bahan baku untuk keperluan industri. Oleh karena kawasan industri harus berada pada jangkauan pelayanan arteri primer. Dalam melakukan analisis ini penulis menggunakan aplikasi ArcGis untuk mengukur jangkauan pelayanan jalan arteri primer. 
Dari hasil analisis diketahui bahwa Kawasan Industri Millennium berada pada radius $3 \mathrm{~km}$ dari jalan arteri primer yaitu J. Raya Serang yang berarti masih dalam lingkup $5 \mathrm{~km}$ dari jalan arteri primer. Analisis ini disesuaikan dengan Destralita (2015) bahwa lokasi kawasan industri sesuai jika berada pada radius $5 \mathrm{~km}$ dari jalan arteri primer. Maka Kawasan Industri Millennium telah berada kawasan yang dalam lingkup jangkauan jalan arteri primer.

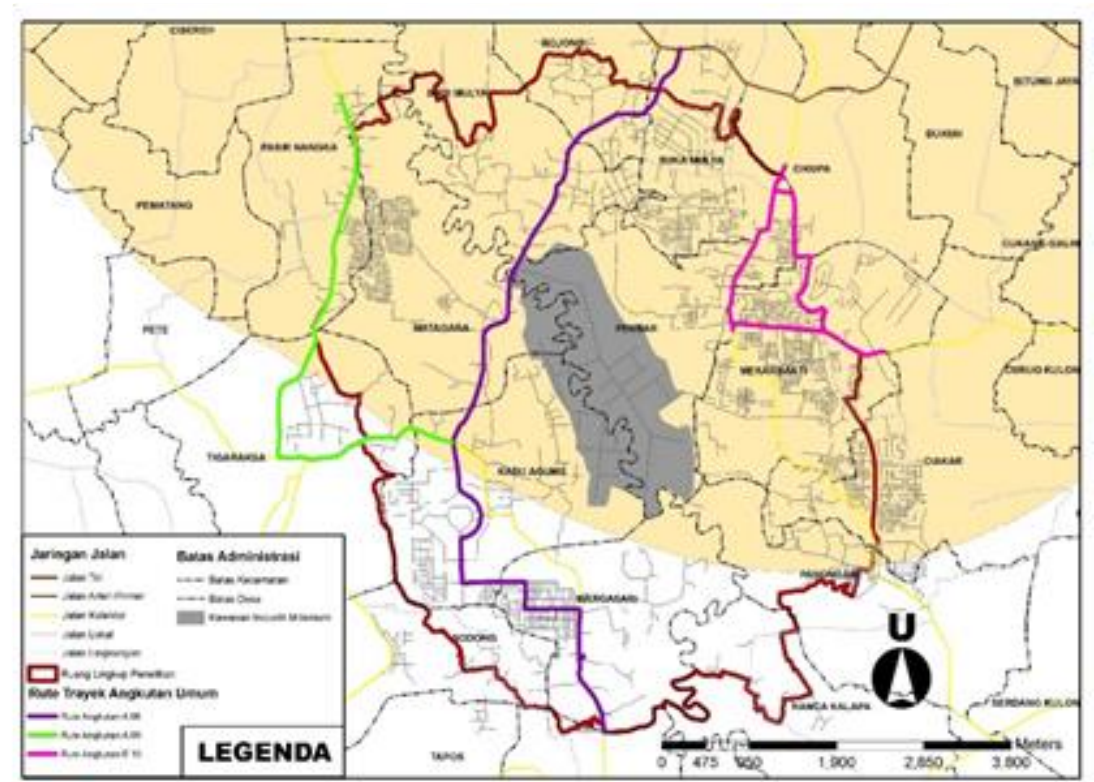

Gambar 6. Peta Trayek Angkutan Umum dan Jangkauan Jalan Arteri Primer

\section{c. Ketersediaan Infrastruktur Kawasan Industri}

Ketersediaan infrastruktur kawasan industri dilihat berdasarkan Permenperin No 35 Tahun 2010 perusahaan kawasan industri harus mengusahakan penyediaan prasarana dan sarana, sekurang-kurangnya antara lain jaringan jalan dalam kawasan industri sesuai ketentuan yang berlaku, saluran drainase, instalasi penyediaan air bersih, IPAL, instalasi penyediaan dan jaringan distribusi tenaga listrik, instalasi penyediaan dan jaringan distribusi/pipa gas, jaringan telekomunikasi, penerangan jalan, unit perkantoran kawasan industri, unit pemadam kebakaran, perumahan bagi pekerja industri untuk kawasan industri yang memiliki luas lebih dari 200 ha, dan fasilitas umum seperti lapangan, masjid, gereja, pertokoan, dll. Kelengkapan infrastruktur pada kawasan industri akan meningkatkan produksi dan mengurangi polusi yang diakibatkan aktivitas industri. Kawasan Industri Millennium dilengkapi dengan sarana prasarana berupa bangunan komersial, pergudangan, perkantoran, klinik kesehatan, lapangan olahraga, area pengolahan limbah B3, water treatment plant, pembangkit listrik, jaringan pipa gas, jaringan internet dan jaringan telekomunikasi. Sarana lain yang disediakan yaitu pemadam kebakaran, masjid di setiap pabrik, dan mesin ATM untuk mempermudah aktivitas tenaga kerja pada kawasan tersebut. Dari hasil observasi tersebut didapatkan bahwa Kawasan Industri Millennium telah memiliki sarana dan prasarana yang lengkap sesuai dengan Permenperin № 35 Tahun 2010. Hal ini mengindikasikan bahwa Kawasan Industri Millennium telah terintegrasi dengan wilayah sekitarnya terkait hal infrastruktur karena telah memiliki infrastruktur penunjang kegiatan industri yang lengkap.

\section{d. Ruang Terbuka Hijau Publik}

Variabel ruang terbuka hijau publik dinilai berdasarkan 2 hal yaitu ketersediaan dan keterjangkauannya. Ketersediaan ruang terbuka hijau publik dihitung berdasarkan SNI 03-1733-2004 dengan cara membandingkan luas lahan RTH publik yang ada pada kawasan penelitian dengan luas lahan minimal yang seharusnya ada untuk melayani penduduk yang tinggal di sekitar Kawasan Industri Millennium. Luas lahan RTH minimal pada kawasan penelitian dengan jumlah penduduk sebanyak 103.255 jiwa adalah seluas 2.7 ha. Pada kondisi eksistingnya kawasan penelitian memliki lahan ruang terbuka hijau seluas 3,325 ha yang terdiri sebagai berikut (lihat Tabel 4). 
Tabel 4. Ruang Terbuka Hijau Publik pada Sekitar Kawasan Industri Millennium

\begin{tabular}{|c|c|c|c|}
\hline Naman RTH Publik & Jenis RTH & Alamat & Luas (ha) \\
\hline $\begin{array}{l}\text { Lapangan sepak bola SMPN } 2 \\
\text { Tigaraksa }\end{array}$ & Lapangan olahraga & Jl. Aria Jaya Santika & 0,59 \\
\hline Lapangan Tigaraksa & Lapangan olahraga & Jl. Syekh Mubarok & 0,56 \\
\hline Lapangan Desa Ciakar & Lapangan olahraga & Desa Ciakar & 1,65 \\
\hline Taman Adiyasa & Taman Lingkungan & $\begin{array}{l}\text { Jl. Taman Adiyasa (Komplek Pemerintahan } \\
\text { Kabupaten Tangerang) }\end{array}$ & 1 \\
\hline Taman Aspirasi & Taman Lingkungan & $\begin{array}{l}\text { Jl. Taman Adiyasa (Komplek Kantor } \\
\text { Pemerintahan Kabupaten Tangerang) }\end{array}$ & 0,96 \\
\hline Taman Ramah Bermain Anak & Taman Lingkungan & $\begin{array}{l}\text { Jl. Taman Adiyasa (Komplek Kantor } \\
\text { Pemerintahan Kabupaten Tangerang) }\end{array}$ & 0,15 \\
\hline Lapangan Citra Raya & Taman lingkungan & Jl. Citra Raya Boulevard & 0,6 \\
\hline Taman Sukamulya & Taman Lingkungan & Desa Sukamulya & 1,84 \\
\hline Taman Desa & Taman Lingkungan & Desa Sukamulya & 0,4 \\
\hline Alun-Alun Kabupaten Tangerang & Taman kota & $\begin{array}{l}\text { Jl. M. Atiek Soewardia Komplek Kantor } \\
\text { Pemerintahan Kabupaten Tangerang) }\end{array}$ & 4 \\
\hline Tempat Pemakaman Umum (TPU) & Pemakaman & Desa Mekarbakti & 2,27 \\
\hline
\end{tabular}

Dari hasil observasi, diketahui bahwa pada kawasan penelitian Kawasan Industri Millennium telah memiliki RTH publik yang telah melampaui luas lahan minimal yang seharusnya tersedia. Maka dapat disimpulkan bahwa kawasan penelitian telah memenuhi terintegrasi pada ketersediaan ruang terbuka hijau publik.

Keterjangkauan RTH publik juga diukur berdasarkan SNI 03-1733-2004 yang menyatakan bahwa radius pelayanan untuk taman lingkungan dan lapangan olahraga yaitu sejauh $1.000 \mathrm{~m}$. Sebaran RTH publik selanjutnya dipetakan dan diukur keterjangkauannya melalui aplikasi ArcGis diperoleh hasil seperti berikut (lihat Gambar 7).

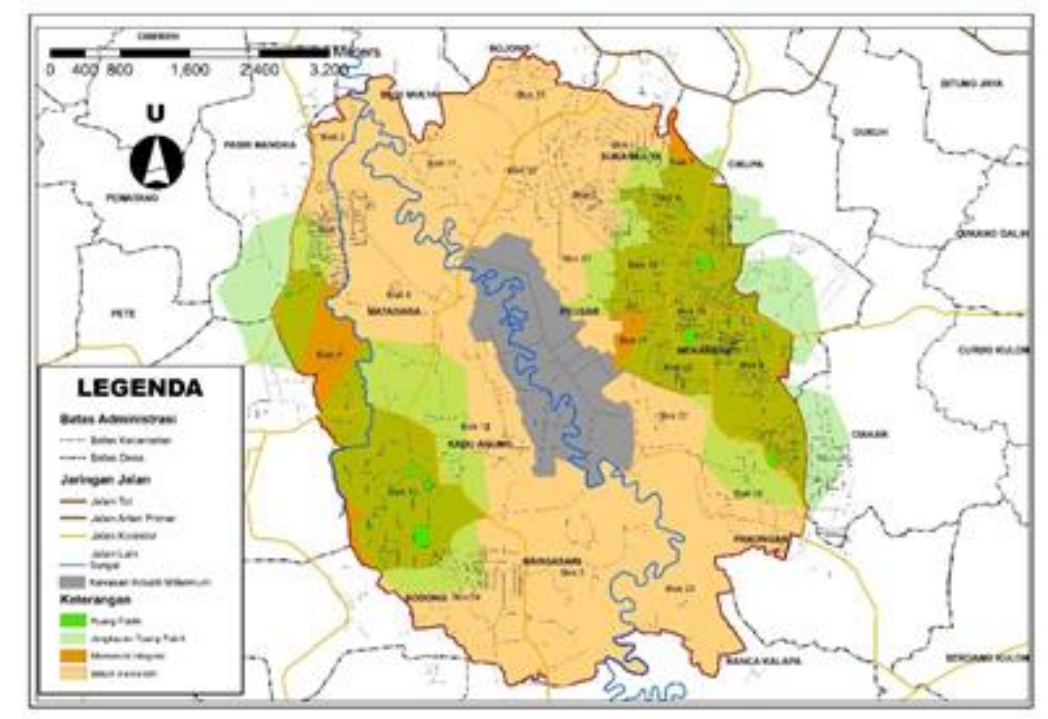

Gambar 7. Peta Jangkauan Pelayanan RTH Publik

Dari peta tersebut dapat diketahui bahwa hanya 9 blok dari 24 blok wilayah penelitian yang terjangkau radius pelayanan RTH publik. Hal ini mengindikasikan secara keterjangkauan RTH publik belum seluruhnya menjangkau kawasan penelitian sehingga dapat disimpulkan bahwa kawasan penelitian masih belum terintegrasi dalam hal keterjangkauan pelayanan $\mathrm{RTH}$ publik.

\section{e. Lokasi Permukiman}

Lokasi permukiman yang terintegrasi dengan kawasan industri adalah lokasi dimana permukiman yang tidak terkena dampak polusi dari kegiatan industri. Mengacu pada Permenperin No 35 Tahun 2010 menyatakan bahwa kawasan permukiman hendaknya berada sejauh $2 \mathrm{~km}$ dari kawasan industri dengan tujuan untuk menghindari dampak negatif yang ditimbulkan oleh kegiatan industri terhadap kawasan permukiman. Dasar inilah yang digunakan untuk menganalisis apakah dalam radius zona $2 \mathrm{~km}$ terdapat pengembangan permukiman atau tidak di kawasan penelitian. 
Dari hasil observasi dan memetakan lokasi zona permukiman di kawasan penelitian, dapat diketahui bahwa pada kawasan penelitian banyak permukiman yang berkembang dalam radius $2 \mathrm{~km}$ dari Kawasan Industri Millennium. Hal ini mengindikasikan bahwa pengembangan Kawasan Industri Millennium belum sesuai dengan Permenperin No 35 Tahun 2010. Sehingga dapat disimpulkan bahwa Kawasan Industri Millennium belum terintegrasi dengan wilayah sekitarnya dalam hal lokasi permukiman.

Lokasi kawasan industri yang berdekatan dengan kawasan permukiman memicu timbulnya dampak polusi yang akan dirasakan oleh masyarakat disekitar kawasan industri. Damayanti (2010) menyatakan bahwa adanya industri akan menimbulkan dampak pada lingkungan sejauh $2 \mathrm{~km}$. Oleh karena itu, untuk mengidentifikasi adanya dampak lingkungan dari Kawasan Industri Millennium dilakukan kuesioner kepada penduduk setempat, tentang dampak lingkungan apa yang mereka rasakan dengan adanya Kawasan Industri Millennium. Dari hasil kuesioner, diketahui bahwa di sebagian wilayah, masyarakat merasa terdampak polusi dari kegiatan industri di Kawasan Industri Millennium. Dampak yang dirasakan masyarakat yaitu berupa asap hasil pembakaran besi/baja, serta kondisi air tanah yang semakin buruk karena pencemaran air. Dari hasil identifikasi ini maka dapat dikatakan bahwa Kawasan Industri Millennium belum terintegrasi dengan wilayah sekitarnya terkait dampak dari kegiatan industri karena sebagian masyarakat merasakan dampak polusi udara yang merupakan efek dari kegiatan industri peleburan besi dan baja di Kawasan Industri Millennium. Berikut adalah peta sebaran wilayah yang terkena dampak polusi berdasarkan kuesioner (lihat Gambar 8).

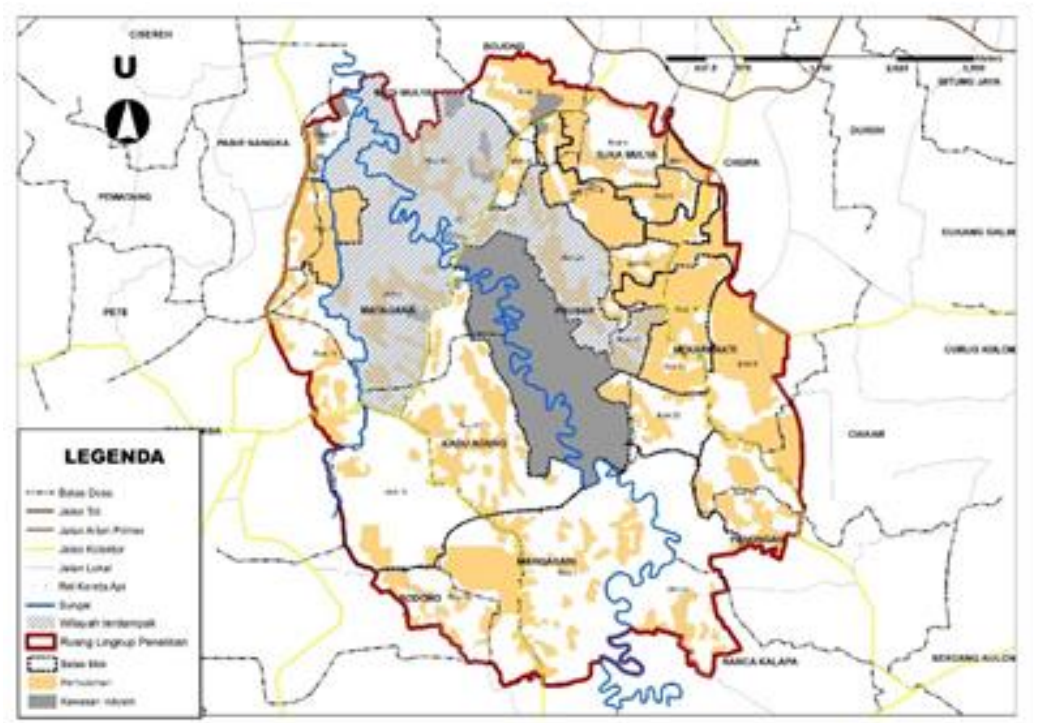

Gambar 8. Peta Sebaran Permukiman dan Lokasi Terdampak Polusi Industri

Untuk membentuk suatu kota industri yang terintegrasi, maka perlu adanya kerja sama antara pihak pengelola industri dengan pengembangan permukiman di sekitarnya. Kawasan Industri Millennium dikembangkan oleh PT Bumi Citra Permai yang hanya mengembangkan kawasan industri dan PT Bumi Citra Permai juga belum menyediakan perumahan bagi pekerja mereka. Pengembangan permukiman di sekitar kawasan industri dikelola oleh pengembang perumahan dan penduduk setempat. Kawasan Industri Millennium belum turut serta dalam pengelolaan permukiman di sekitarnya untuk penyediaan rumah layak atau program lain. Data kondisi eksisting tersebut mengindikasikan bahwa Kawasan Industri Millennium belum terintegrasi dalam hal keterkaitan dalam manajemen permukiman disekitarnya.

Dari hasil analisis di masing-masing variabel dan sub variabel maka dapat dirangkum hasilnya yang tertera pada Tabel 5.

Tabel 5. Rangkuman Hasil Analisis Masing-Masing Sub Variabel

\begin{tabular}{|c|c|c|c|}
\hline Variabel & Sub Variabel & Hasil Penelitian & Keterangan \\
\hline $\begin{array}{c}\text { Pemisahan } \\
\text { Penggunaan }\end{array}$ & Rencana pemisahan lahan & $\begin{array}{c}\text { Adanya Perda Kabupaten Tangerang No } 9 \\
\text { Tahun } 2006 \text { yang mengatur untuk penyediaan } \\
\text { RTH sebagai zona transisi industri dengan } \\
\text { permukiman }\end{array}$ & Memenuhi indikator \\
\hline Lahan & $\begin{array}{l}\text { Penggunaan lahan eksisting } \\
\text { (pemisahan penggunaan } \\
\text { lahan) }\end{array}$ & $\begin{array}{c}\text { Masih terdapat wilayah yang belum ada zona } \\
\text { transisi antara industri Millennium dengan } \\
\text { permukiman }\end{array}$ & $\begin{array}{l}\text { Belum memenuhi } \\
\text { indikator }\end{array}$ \\
\hline
\end{tabular}




\begin{tabular}{|c|c|c|c|}
\hline Variabel & Sub Variabel & Hasil Penelitian & Keterangan \\
\hline \multicolumn{2}{|c|}{ Konektivitas Antar Guna Lahan } & $\begin{array}{c}\text { Wilayah penelitian terbagi menjadi } 3 \text { tingkatan } \\
\text { integrasi sedang, rendah dan tinggi }\end{array}$ & $\begin{array}{l}\text { Belum memenuhi } \\
\text { indikator }\end{array}$ \\
\hline \multirow{3}{*}{ Aksesibilitas } & Tingkat pelayanan jalan & $\begin{array}{l}\text { Tingkat pelayanan jalan pada jalan yang dilalui } \\
\text { kendaraan industri paling tingai adalah kelas C }\end{array}$ & Memenuhi indikator \\
\hline & $\begin{array}{l}\text { Ketersediaan moda } \\
\text { transportasi angkutan umum }\end{array}$ & $\begin{array}{l}\text { Terdapat } 3 \text { trayek angkutan umum yang } \\
\text { melayani kawasan penelitian }\end{array}$ & Memenuhi indikator \\
\hline & $\begin{array}{l}\text { Ketersediaan jalur distribusi } \\
\text { industri }\end{array}$ & $\begin{array}{l}\text { Kawasan Industri Millennium berada pada } \\
\text { radius } 3 \mathrm{~km} \text { dari jalan arteri primer }\end{array}$ & Memenuhi indikator \\
\hline Infrastruktur & $\begin{array}{l}\text { Kelengkapan infrastruktur } \\
\text { industri }\end{array}$ & $\begin{array}{l}\text { Kawasan Industri Millennium memiliki sarana } \\
\text { dan prasarana yang lengkap sesuai standar }\end{array}$ & Memenuhi indikator \\
\hline \multirow{2}{*}{$\begin{array}{l}\text { Ruang } \\
\text { Terbuka Publik }\end{array}$} & $\begin{array}{l}\text { Ketersediaan ruang terbuka } \\
\text { publik }\end{array}$ & $\begin{array}{l}\text { Luas RTH mencapai } 3,325 \text { ha dan telah } \\
\text { melebih luas lahan minimal untuk kawasan } \\
\text { penelitian }\end{array}$ & Memenuhi iindikator \\
\hline & $\begin{array}{l}\text { Keterjangkauan ruang } \\
\text { terbuka publik }\end{array}$ & $\begin{array}{l}\text { Hanya terdapat } 9 \text { blok wilayah penelitian dari } \\
24 \text { blok yang terjangkau pelayanan RTH publik }\end{array}$ & $\begin{array}{l}\text { Belum memenuhi } \\
\text { indikator }\end{array}$ \\
\hline \multirow{4}{*}{$\begin{array}{l}\text { Permukiman } \\
\quad \text { Tidak } \\
\text { Terdampak } \\
\text { Negatif dari } \\
\text { Industri }\end{array}$} & Jarak Permukiman & $\begin{array}{l}\text { Terdapat permukiman seluas } 1.114 \text { ha di } \\
\text { dalam radius } 2 \mathrm{~km} \text { dari Kawasan Industri }\end{array}$ & $\begin{array}{l}\text { Belum memenuhi } \\
\text { indikator }\end{array}$ \\
\hline & & Millennium & \\
\hline & $\begin{array}{l}\text { Dampak kegiatan industri } \\
\text { terhadap permukiman }\end{array}$ & $\begin{array}{l}\text { Sebagaian masyarakat mengeluhkan dampak } \\
\text { polusi dari Kawasan Industri Millennium }\end{array}$ & $\begin{array}{l}\text { Belum memenuhi } \\
\text { indikator }\end{array}$ \\
\hline & $\begin{array}{l}\text { Keterlibatan manajemen } \\
\text { permukiman oleh industri }\end{array}$ & $\begin{array}{c}\text { Pengelola Kawasan Industri Millennium hanya } \\
\text { mengembangkan kawasan industri dan tidak } \\
\text { pernah terlibat dalam manajemen permukiman } \\
\text { di sekitarnva }\end{array}$ & $\begin{array}{l}\text { Belum memenuhi } \\
\text { indikator }\end{array}$ \\
\hline
\end{tabular}

Berdasarkan hasil penelitian, diketahui dari 12 sub variabel karakteristik kota industri hanya terdapat 6 sub variabel yang memenuhi indikator integrasi dengan Kawasan Industri Millennium. Oleh karena itu dapat disimpulkan bahwa dalam menuju kota industri, integrasi Kawasan Industri Millennium telah mencapai $50 \%$ elemen pengembangannya.

\section{KESIMPULAN}

Berdasarakan hasil penelitian, Kawasan Industri Millennium telah memenuhi indikator integrasi pada 6 sub variabel untuk menuju kota industri. Sub variabel tersebut yaitu rencana pemisahan guna lahan, tingkat pelayanan jalan, moda transportasi angkutan umum, jalur distribusi industri, infrastruktur kawasan industri, dan ketersediaan ruang publik. Sementara itu 6 sub variabel perlu dintegrasikan oleh Kawasan Industri Millennium dengan wilayah sekitarnya yaitu pemisahan guna lahan eksisting, konektivitas, jangkauan pelayanan ruang publik, lokasi permukiman, dampak kegiatan industri dan keterkaitan manajemen industri. Permasalahan yang timbul memerlukan kerja sama antara pihak manajemen kawasan industri, pemerintah Kabupaten Tangerang, dan penduduk setempat agar tercipta suatu kota industri yang terintegrasi. Diperlukan juga pengawasan dan ketegasan dari pemerintah mengenai aturan terkait dampak kegiatan industri dan aturan yang berlaku dalam pengembangan kawasan industri.

\section{DAFTAR PUSTAKA}

Abdullah (2010). Pengaruh Perkembangan Industri terhadap Pola Pemanfaatan Lahan di Wilayah Kecamatan Bergas Kabupaten Semarang. Tesis. Semarang: Universitas Diponegoro. Diakses dari http://eprints.undip.ac.id/23597/1/ABDULLAH.pdf

Audistiana, A., Widiana, M. E., \& Negoro, B. K. (2017). Pengaruh Aksesibilitas, Fasilitas dan Kepuasan Pelanggan Terhadap Loyalitas Pelanggan di Delta Fishing Sidoarjo. Jurnal Manajemen Branchmark, 3(3), 29 . Diakses dari http://fe.ubhara.ac.id/ojs/index.php/ebranchmarck/article/view/537/513

Betten, N., \& Mohl, R. (1974). The Evolution of Racism in an Industrial City, 1906-1940: A Case Study of Gary, Indiana. The Journal of Negro History, 59(1), 51-64. http://doi.org/10.2307/2717140

Catanese, A. J. \& Snyder, J. C. (1988). Perencanaan Kota. Jakarta: Penerbit Erlangga.

Damayanti, Rully. (2010). Pertumbuhan Fisik Kota Karena Pengaruh Industrialisasi, Studi Kasus Kota Ahmedabad - India. Yogyakarta: UGM

Departemen Pekerjaan Umum Direktorat Jenderal Bina Marga (1997). Manual Kapasitas Jalan Indonesia (MKJI). Diakses dari: https://www.academia.edu/16746001/Manual_Kapasitas_Jalan_Indonesia_MKJI_ 
Destralita, N. C., \& Rahmawati, D. (2015). Kriteria Zona Industri Pendukung Pengembangan Kawasan Agropolitan di Kabupaten Tuban. Jurnal Teknik ITS, 4(2). Diakses dari http://ejurnal.its.ac.id/index.php/teknik/article/view/10933

Dirdjojuwono, R. W. (2004). Kawasan Industri Industri: Sebuah Konsep Perencanaan dan Aplikasinya. Bogor: Pustaka Wirausaha Muda.

Fachira, F. (2017). Kabupaten Tangerang Percepat Pembangunan Tiga Kawasan Industri. Diakses dari https://deladeni.com/metro/146-kabupaten-tangerang-percepat-pembangunan-tiga-kawasan-industri

Harris, R. (2009), 'Industrial City', in K. Rob and T. Nigel (Ed.) International Encyclopedia of Human Geography. Amsterdam: Elsevier.

Nurmayanti. (2017). Kota Industri Bisa Jadi Solusi Pemerataan Ekonomi. Diakses dari https://www.liputan6.com/bisnis/read/2933897/kota-industri-bisa-jadi-solusi-pemerataan-ekonomi

Perda Kabupaten Tangerang No 9 Tahun 2006 tentang Rencana Tapak. Diakses dari http://jdih.tangerangkab.go.id/apps/www/storage/document/Perda-9-2006-Rencana-Tapak.PDF

Permen PU No.16/PRT/M/2009 tentang Pedoman Penyusunan Rencana Tata Ruang Wilayah Kabupaten. Diakses dari http://birohukum.pu.go.id/uploads/DPU/2009/PermenPU16-2009.pdf

Permenperin No. 35/M-IND/PER/3/2010 tentang Pedoman Teknis Kawasan Industri. Diakses dari http://jdih.kemenperin.go.id/site/download_peraturan/1520

Phelps, R. (1995). The Search for a Modern Industrial City: Urban Planning, the Open Shop, and the Founding of Torrance, California. Pacific Histrical Review, 64(4), 504-517. https://doi.org/10.2307/3640556

Prabhakar, S. (2015). Industrial Town in India. Diakses dari https://www.slideshare.net/prabhakarsubramani/industrial-towns-in-india

Saraswati, A. A. (2008). Keberadaan Ruang Terbuka Hijau dalam Pembangunan Kawasan Industri. Jurnal Teknik Lingkungan, 1-2. http://www.kelair.bppt.go.id/Jtt/2008/khusus/01ruanghijau.pdf

Siregar, J. P. (2014). Metodologi Dasar Space Syntax dalam Analisis Konfigurasi Ruang. Malang: Jurusan Perencanaan Wilayah dan Kota Universitas Brawijaya.

Sitorus, S. R. (2016). Perencanaan Penggunaan Lahan. Bogor: IPB Press.

SNI 03-1733-2004 Tentang Perencanaan Tata Cara Perencanaan Lingkungan Perumahan di Perkotaan. Diakses dari http://sni.litbang.pu.go.id/index.php?r=/sni/new/sni/detail/id/694

Suchaini, U. (2013). Industrial District: Fenomerna Aglomerasi dan Karakteristik Lokasi Industri. Jakarta Timur: Dapur Buku.

Sukandar, E., \& Wijaya, H. B. (2015). Eksternalitas Kegiatan Industri Terhadap Kinerja Jalan (Studi Kasus Jalan Sadang-Batas Purwakarta/Subang). Jurnal Pembangunan Wilayah \& Kota, 11(2), 170. https://doi.org/10.14710/pwk.v11i2.10846

Sutanta (2010). Faktor-Faktor Penyebab Tidak Berkembangnya Kawasan Industri Nguter Kabupaten Sukoharjo. Tesis. Semarang: Universitas Diponegoro. http://eprints.undip.ac.id/24067/1/SUTANTA.pdf

Tarigan, R. (2005). Perencanaan Pengembangan Wilayah. Jakarta: Bumi Aksara.

UU Nomor 3 Tahun 2014 Tentang Perindustrian. Diakses dari http://www.kemenperin.go.id/download/5181/Undang-Undang-No-3Tahun-2014-Perindustrian

Wiebenson, D. (1960). Utopian Aspect of Tony Garnier's Cite Industrielle. Journal of the Society of Architectural Historians, 19(1), 1624. https://doi.org/10.2307/987962 